Imperial Majesty and the President of the Haile Sellassie University to hold the next Conference at Addis Ababa, probably in the spring of 1966 . There was unanimous agreement as to the necessity of preserving in their entirety the published works of the present intellectual and literary revival of the ancient heritage of Ethiopia and the importance of practical steps being taken by the appropriate Ethiopian authorities for that purpose. The Conference also recognized the need for a census or register of all Ethiopian medieval churches together with the manuscripts and works of art they might contain.

The papers and proceedings of the Conference are to be published early in 1964 in a double issue of the Journal of Semitic Studies, edited by Professor Beckingham and Professor Ullendorff.

\title{
International Institute of Differing Civilisations: Study Session in Palermo
}

The International Institute of Differing Civilisations (Incidi) held its 33 rd study session in Palermo from 23 to 27 September, under the patronage of Professor Antonio Segni, President of the Italian Republic. The subject chosen for discussion was 'The Constitutions and Administrative Institutions of the New States' and the session was attended by I60 participants from all parts of Europe, Africa, Asia, and the U.S.A. His Excellency Professor G. Ambrosini, President of the Constitutional Court in Rome and President of Incidi, was in the chair. General reports on the political aspects of the subject had been prepared by the Centre of Political Studies of Lovanium University; the juridical aspect by Professor F. Luchaire, Director of the Institut des Etudes d'Outremer, Paris; the social aspect by Mr. Guy Hunter of the Institute of Race Relations, London; and the economic aspect by Mr. C. N. Vakil of Bombay, former Director of the Unesco Research Centre for Southern Asia. Over thirty regional reports were also circulated. The papers, proceedings and discussions are to be published in a forthcoming issue of Civilisations. The theme chosen for the 1965 session is 'The political, social and economic aspects of urban agglomerations in developing countries'.

\section{Inter-State Relations in Africa: Seminar at Freiburg im Breisgau}

THE Arbeitsstelle für kulturwissenschaftliche Forschung, Freiburg, and the Institute of Commonwealth Studies of the University of London held a joint seminar on 'Inter-State Relations in Africa' at the Studienhaus, Wiesneck,'near Freiburg, from 2x to 26 October 1963.

Among the subjects on which papers were presented to the seminar were:

'Pan-Africanism 1957-63' (Dennis Austin, London).

'The Part Played by the Independent African States in the Congo Crisis' (Catherine Hoskyns, London).

'Contemporary African Groupings: Ideas and Methods of Integrating Independent African States' (Ronald Nagel, Freiburg).

'The Relevance of Educational Differences and of Common Efforts for Educational Development to the Problem of Wider Union' (Hans N. Weiler, Freiburg).

'Closer Union in East Africa' (Edward A. Brett, London).

'Rwanda and Burundi: A Case Study of the Impact of Internal Social and Political Problems on the External Relations of African States' (Theodor Hanf, Freiburg).

"The "Union Africaine et Malgache" " (Keith Panter-Brick, London).

'France, the European Economic Community and Africa, 1945-1963' (Franz Ansprenger, Berlin).

'Pan-Africanism: Some Economic Considerations' (Michael McWilliam, London).

Professors Kenneth E. Robinson (London) and Dieter Oberndörfer (Freiburg) acted as chairmen of the discussion. It is hoped to publish the papers, revised in the light of the discussion in the seminar. 